\section{Hrabovskyi Y., Yevsyeyev 0.}

\title{
DEVELOPMENT OF METHODOLOGICAL PRINCIPLES OF SUPPORT-PRESERVATION ENGINEERING WORK
}

Об’єктом дослідження є облік особливостей перенесення кольорів у процесі додрукарської підготовки видання. Одним з найбільш проблемних місць є ручне управління кольором, яке часто робиться емпіричним шляхом, методом простих проб і помилок, що негативно впливає на якість продукції.

В ході дослідження використовувалися системний підхід, методи аналізу та синтезу. Визначено характерні особливості кольору з точки зору роботи препрес-інженера. 3'ясовано, що основними моментами, які завжди необхідно враховувати при проведенні додрукарсъкої підготовки, є режим послідовного перенесення фарби і режим друку накладенням.

Запропоновано технологію управління сумішевими кольорами. Результатом реалізації даної технологї виявилися наступні рекомендації:

- для створення градієнтних заливок і інших подібних ефектів з переходом «у біле» в якості кінцевого значення білого кольору слід застосовувати початковий сумішевий колір зі значенням Тint=0\%;

- для створення градієнтних заливок і інших подібних ефектів з переходом «в прозоре» надійніше застосовувати режим переходу «у біле» з установкою атрибуту друку з накладенням;

- для створення складних взаємодій між тріадними і сумішевими кольорами слід застосовувати комбінацї об’єктів з використанням атрибуту друку з накладенням.

Спроектовано алгоритм обліку особливостей перенесення кольорів. В результаті було вирішено основні протиріччя щодо використання кольору, та отримано методичні рекомендації підтримки препрес-інженера з урахуванням правильного кольоровідтворення.

Здійснено автоматизацію процесу визначення параметрів трепінгу. Ця автоматизація надає препрес-інженеру наступні можливості:

- створення бази даних, файлів оперативної інформацї̈ стосовно перенесення кольорів;

- отримання рекомендацій стосовно аналізу окремих об'єктів на різних етапах роботи;

- подальше використання інформащійно-підтримувальної системи в якості довідника.

Завдяки цьому забезпечується діючий інструментарій стосовно підтримки додрукарських процесів та отримати певні ефекти від впровадження у виробнищтво. Зокрема, може бути підвищена продуктивність технологічного процесу додрукарської підготовки та знижена його собівартість.

Ключові слова: методичні засади підтримки роботи препрес-інженера, інформаційно-підтримувальна система, контроль якості перенесення кольорів.

\section{Introduction}

The development of high-quality printing products is possible only if effective prepress preparation is carried out. At the pre-print stage, the edition will look appropriate if it matches a number of technical parameters, among which the most important are color options. Thus, for the prepress engineer there is a problem of obtaining qualitative products, which should be structured and reduced to several subordinate tasks, observing these parameters. In turn, each of these tasks is decomposed into a series of certain more detailed conditions. However, there is a problem of the absence of such structured stages of the work of the prepress engineer with the account of the peculiarities of color rendering.

Thus, in the process of preparing the layout for printing there is a lot of difficulties associated with the need for the prepress engineer to solve a series of step-by-step tasks to ensure the quality of color reproduction. Therefore, it is important to develop a methodology for the support of the work of the prepress engineer, which will enable active tools in support of prepress processes and obtain certain effects from the introduction into production. In particular, the productivity of the technological process of prepress preparation and its cost price may be increased.

\section{The object of research and its technological audit}

The object of research is the accounting of the characteristics of color rendering in the process of preprint preparation of the publication.

Nowadays there is a huge amount of measuring equipment for quality control of color rendering. However, for most enterprises (especially for printers of advertising polygraphy), these devices are expensive and increase the deadline for the execution of orders. Therefore, quality control of the color of printing products is mainly carried out at the preprint stage.

In most cases, the preprinting worker is advising on color-optimization issues with the printer, as the printer 
is the most competent in this regard. In this case, the recommendations regarding color processing received from the printer have a number of significant drawbacks, which mainly consist in the fact that the information received is not specific and unsystematized. In addition, the counseling process takes a lot of time both from the printer and the prepress engineer. In cases where it is not possible to contact the printer, such «manual» color management is often done empirically, by simple sampling and error, which greatly affects the quality of the product.

\section{The aim and objectives of research}

The aim of research is development of methodological support for the work of the prepress engineer. This will make it possible to achieve interoperability between the components of the layout check process and the correct rendering of colors.

To achieve this aim, the following tasks must be solved:

1. To identify the specific features of color in terms of the work of prepress engineer.

2. To offer mixed-color management technology.

3. To design the algorithm of account of color rendering peculiarities.

4. To automate the process of determining the trapping parameters.

\section{Research of existing solutions of the problem}

Fast-paced digital technologies supplant the traditional analogue stages of printing processes and provide broad opportunities for addressing the pressing problems facing the industry. Consequently, modern literature attaches great importance to the problems of informational and methodological support of prepress processes.

Thus, in the work [1] systematized information on the leading tendencies of information support of preprint processes. However, the peculiarities of the processing of color images and, accordingly, the information support of this processing have not been addressed in the document.

In the research [2], the technology of formation of color shades in detail is considered. However, there is no record of the peculiarities of color rendering in the pre-printing process in this document.

The issue of optimizing the printing for thin conducting drawings is dedicated to research [3]. However, this work does not take into account the specifics of print optimization under the condition of mixed colors.

An overview of image processing methods is given in the work [4]. In this work, particular attention is paid to aspects of image processing, such as image acquisition, image enhancement, image segmentation, function deletion, image classification. But, with a detailed coverage of various methods of image processing, the research [4] does not take into account the characteristic features of preprint processes in the publishing and printing industry.

The paper [5] describes a method for assessing the effectiveness of an information system from the standpoint of an intellectual property object, which can be used to optimize the information support of prepress processes. But the limitation of the use of this method in printing is the lack of a detailed algorithm of work in accordance with the specific tasks of the prepress engineer.
Features of the use and optimization of color schemes of images are considered in the research [6]. However, this work does not contain information regarding the specificity of color optimization in terms of the work of the prepress engineer.

In the research [7], based on the example of printing on a fabric, an analysis of the rendering of paint to the material that is printed is given. The order of observance of mixed paints is determined in this paper. However, this study does not include practical recommendations regarding the achievement of interoperability between the components of the layout check process for the correct rendering of colors.

The work is devoted to the issue of quality control of preprint editions [8]. In this work are analyzed in detail the peculiarities of the construction and principles of operation of control and measuring devices for maintaining the work of the prepress engineer. But in this work there is no analysis of possibilities and the algorithm of the work of the information-support system of the prepress engineer.

Principles of development and features of the use of adaptive algorithms for image processing for printing are given in scientific work [9]. However, this study does not allow to provide comprehensive recommendations regarding the support of the prepress engineer.

The research [10] provides methodological recommendations for assessing the quality of preprint preparation of the book. However, the author of the study does not touch upon the management of the process of color image processing.

The work [11] proposes an informational model of prepress digital workflow and text and graphic information transformations. The developed model describes the organization of the process of color management at all stages of preprinting. However, this study does not take into account the characteristics of the color rendering and does not include a sound mixing color management technology.

Thus, the analysis of scientific research on the problems of support of the work of the prepress engineer shows that the researchers did not have a holistic, scientifically sound methodology for improving the accounting of peculiarities of color rendering in the process of preprint preparation of the publication.

\section{Methods of research}

5.1. Characteristic features of color in terms of the work of the prepress engineer. The main points that always need to take into account when conducting preprinting are the regime of consistent rendering of paint and the mode of printing overlay.

The amount of paint rendering depends on many factors. In a series of overlapping of several colors, especially in the «raw» printing mode, each further paint falls on the previous one not completely but with losses. The magnitude of such losses varies from the type of ink and printing mode and can reach 15-50\% [2].

In triad printing, the following order of paints is usually used: CMKY - when printed in two runs on two-color printing machines; KCMY - when printing on multi-colored machines. At the same viscosity of paints the first is usually printed contrasting colors. Such a procedure for applying paints, even if there is a loss in printing, contributes to 
a greater clarity of prints. Of course, the order of applying paints may be different, but in this case the other will be the result.

Do not be surprised if the supplements, printed from the same forms, but with different order of color compliance, will differ significantly in the color rendering.

For mixed colors, this situation, in general, is also preserved. The order of their observance must be determined prior to the beginning of the preparation of the electronic layout.

In practice, taking into account the incomplete rendering of paint can, but only very approximate. Specific numerical values can only be determined by an experienced method. For example, if it is necessary to print half-tone illustrations in one or more paints on homogeneous backgrounds made with metallic paints or glowing whitewashes (when printed on metallic and transparent materials), then it is wise to increase the optical density of these illustrations (especially in the halftones).

5.2. Development of mixed color management technology. By mix colors, all standardized (for example, Pantone) colored, as well as all metallized and special paints [3].

In editors working with vector graphics, any blend color can be specified either from an external library, or arbitrarily in a sample palette (Swatch). The difference between the blend color from the triad consists in assigning it the Spot Color attribute. This very important difference allows you to count all objects painted in the same color Spot, to one separation. This approach means the following: the blend color is displayed on a separate separation based on the name and without any dependence on its screen color representation.

However, publishing applications do not have developed mechanisms of color separation. For example, gradient fill, created in Adobe Illustrator and consisting of two or more mixed colors, is split fairly correctly. But if the gradient fill contains at least one triadic color, then as a result of transformations in the bitmap processor, all mixed colors will be converted to a triad. The same is true for color separations of tone transitions such as Blend, gradient nets, Pattern samples, images processed by special filters and effects. Three simple rules will prevent such negative appearance:

1. For the creation of gradient fills (and other similar effects) with the transition «in white» as the final white value, use the initial blend color with the value Tint $=0 \%$.

2. To create gradient fills (and other similar effects) with the transition «in the transparent» it is more reliable to use the transition mode «in white» with the installation of the printing attribute with the overlay. In this case, the imposition of «white» on any background will not change the color of the background.

3. To create complex interactions between triad and blend colors, you should use combinations of objects using the overprinting attribute.

For example, to implement a gradient transition from a certain Spot blend color to a black triad $(C=0, M=0$, $Y=0, K=100 \%)$ it is necessary to create two identical objects with the following parameters of gradient fill:

- the original color Spot $=100 \%$;

- the final color $S p o t=0 \%$;

- the original color before $=0 \%$;

- the final color before $=100 \%$, and then set the print mode overlaying one object to another.
Improvement in the management of mixed colors should be achieved on the basis of trapping. The procedure of trapping in preprint preparation involves the special processing of borders and sites of the combination of objects of different colors in order to prevent the appearance of the effects of non-moving paints in the printing process. Such defects are caused by nonideal conditions of successive imposition of printing in different sections of the printing press.

The color of the path that performs the trapping function (hereafter - the trapping path), for the colored sequences must be determined by the general rule (light towards the dark), but the appearance of complex colors should be avoided. In most cases, the color of the object's fill or the color of the background on which the object is located can be used for the trap circuit.

If an object or background has a complex color consisting of several triad components, then the color of the contour should only contain one or two predominant components of the color of the object or background. Otherwise, as if it were not necessary to do trapping for the area of trapping. For example:

- object: $C=0, M=80, Y=60, K=0$;

- background: $C=100, M=0, Y=0, K=45$;

- color of the trap circuit: $C=0, M=50, Y=0, K=0$.

Tracking of lines and contours (Outline) should be executed overlay over a contour of its duplicate with the increased thickness. The circuit overlay should be printed overlay (have the Overprint attribute installed). In this case, the edges of the wider overlapping contour will partially overlap the adjacent colored background, creating a trapping area. A similar technique is used for trapping dies (Fill).

Font items can also be considered as dies, so trapping methods for them are used the same.

In this case, increasing the size of objects is achieved by adding a contour with the attribute Overprint (Table 1).

Table 1

The example of using adjusting objects for trapping

\begin{tabular}{|c|c|c|c|c|}
\hline $\begin{array}{c}\text { Number } \\
\text { of layer }\end{array}$ & Object & Color & Overprint & Purpose \\
\hline 1 & $\begin{array}{c}\text { Back- } \\
\text { ground }\end{array}$ & $\begin{array}{c}C=72, M=60, \\
Y=60, K=100\end{array}$ & No need & - \\
\hline 2 & $\begin{array}{c}\text { Contour } \\
0.8 \mathrm{pt}\end{array}$ & $\begin{array}{c}C=0, M=0, \\
Y=0, K=100\end{array}$ & No need & $\begin{array}{c}\text { Corrective contour } \\
\text { for background }\end{array}$ \\
\hline 3 & $\begin{array}{c}\text { Contour } \\
0.5 \mathrm{pt}\end{array}$ & «Land» & No need & $\begin{array}{c}\text { The main «drawing» } \\
\text { contour }\end{array}$ \\
\hline 4 & $\begin{array}{c}\text { Contour } \\
0.8 \mathrm{pt}\end{array}$ & «Land» & Need & $\begin{array}{c}\text { Trapping between the } \\
\text { background and the } \\
\text { graund }\end{array}$ \\
\hline
\end{tabular}

5.3. Development of the algorithm of accounting for the characteristics of the rendering of colors. After defining the main characteristic features of color in the pre-print preparation, the work of the prepress engineer can be divided into certain structured stages or modules, during which it is possible to identify the main contradictions in the use of color. And also to receive methodical recommendations taking into account the correct color reproduction. Information and support system prepress engineer will be developed on the basis of these stages. 
The first stage of work is presented on the Fig. 1.

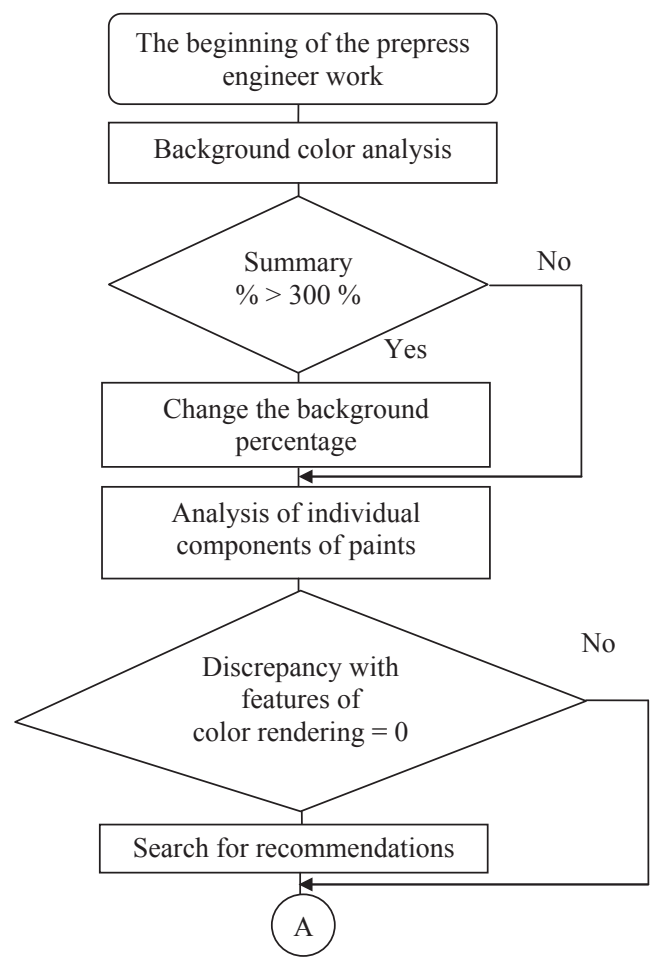

Fig. 1. The first structured stage of prepress engineer «Background Analysis»

The first stage is analysis of the background and identification of its relevance to the characteristic features of the rendering of colors. At this stage, the work of the prepress engineer is to choose the optimal total percentage of colors, which will result in a print with a minimum deviation from the desired result.

The second stage, presented in Fig. 2, consists in analyzing the color parameters of the text, as well as the correlation of these parameters with the font size. At this stage, the prepress engineer can choose the most appropriate font size, as well as get recommendations for color reproduction of the text.

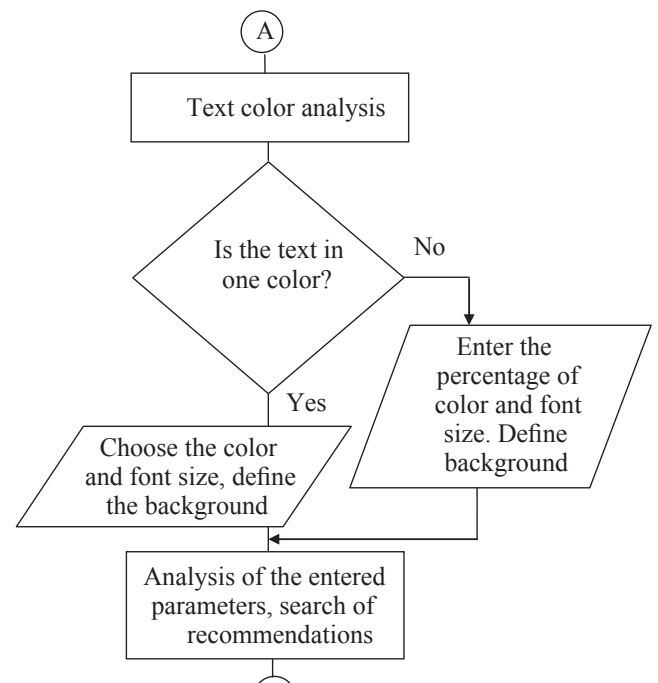

(B)

Fig. 2. The second structured stage of the prepress engineer "Analysis of the text
The third stage, which is depicted in Fig. 3, is the use of prepress engineer under certain conditions of the parameters of trapping and overprint.

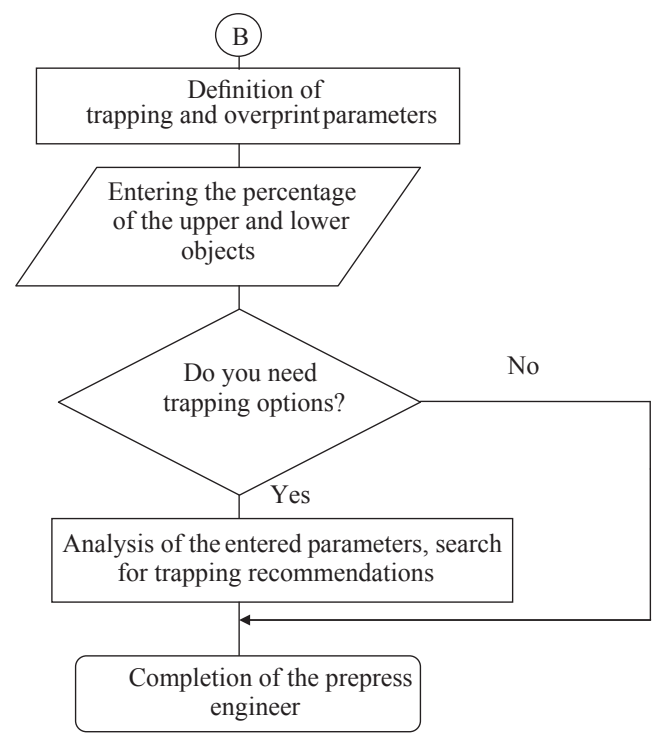

Fig. 3. Third structured stage of prepress engineer «Definition of trapping parameters»

It should be noted that the parameters of trapping and the overprint are determined by analyzing the color of two objects lying on one another.

\section{Research results}

As a result of the research, the information and support system of the prepress engineer was developed, which is designed to solve the problems of accounting for the characteristics of the rendering of colors.

When using this system, the prepress engineer will be able to quickly and easily create a database, at his own discretion, information on the specifics of the rendering of shades of a certain color. In addition, the prepress engineer will be able to receive recommendations on the analysis of individual objects at different stages of work and to use this system in the future as a reference system.

The user has the opportunity to obtain the results of analysis and data processing as separate recommendations. The interface module is built on two types of dialogues: a question-answer dialog and a menu-type dialog.

The input for the program is user input from the keyboard. Output data is:

1) text information (system analysis results) that is displayed;

2) a message about all the errors that have arisen;

3) intermediate data in the form of a total percentage of paints.

The system was designed in several stages:

1) study and analysis of the problem area;

2) formation of data on the color scale;

3 ) identification of the main types of printed papers;

4) definition of the rules of the trap.

Evaluation of the quality of color reproduction of text depends on certain parameters. At the prepress stage it is possible to identify the overwhelming majority of circumstances that may lead to incorrect reproduction of the text. 
Among the main reasons for rejection, it is necessary to distinguish the following:

1) text in the raster;

2) discrepancy of the text to the requirements of font sizes.

The analysis of controlled parameters of prepress processing of the text should be carried out in the context of the main processes of the publishing stage. These parameters are presented in Table 2 .

Table 2

Text options for printing

\begin{tabular}{|c|c|}
\hline Text options & Allowable values \\
\hline \multirow{2}{*}{ The font size is not less than } & 8 pt chopped fonts \\
\cline { 2 - 2 } & $10 \mathrm{pt}$ serif fonts \\
\hline Line thickness not less than & $0.5 \mathrm{pt}$ \\
\hline
\end{tabular}

An equally important stage in the evaluation of color reproduction is the stage of determining the conformity of the total ink color of the type of the printed matter (Table 3).

Correspondence of the total color of the sealed materia

\begin{tabular}{|c|c|c|c|c|}
\hline \multirow{3}{*}{$\begin{array}{c}\text { Total } \\
\text { amount of } \\
\text { paint }\end{array}$} & \multirow{2}{*}{$\begin{array}{l}\text { Offset } \\
\text { рарег }\end{array}$} & \multirow{2}{*}{$\begin{array}{l}\text { Card- } \\
\text { board }\end{array}$} & \multicolumn{2}{|c|}{ Coated рарег } \\
\hline & & & glossy & frosted \\
\hline & $280 \%$ & $300 \%$ & $300 \%$ & $300 \%$ \\
\hline
\end{tabular}

Also at this stage, it is necessary to monitor the parameters of the trap depending on the type of paper. These parameters are presented in Table 4.

The contrast of the resulting image, gloss, and translucence directly depend on the properties of the paper. The choice of paper affects the resolution of the print, the color and gradation characteristics of the print, and so on

Also, the paper parameters cause the results of processing the products at the post-printing stage, including folding, binding, varnishing, laminating.

Increasingly, any printing house is faced with Incompatible paints. Ways to solve this problem should also be considered at the prepress stage. However, often this point is missed in order to save time.

Tahle 4

Parameters trap depending on the type of paper

\begin{tabular}{|c|c|c|c|c|}
\hline Trapping & Offset paper & Cardboard & \multicolumn{2}{|c|}{ Coated paper } \\
\hline \multirow{2}{*}{$\begin{array}{c}\text { Trapping } \\
\text { size }\end{array}$} & $\begin{array}{c}0.5 \mathrm{pt} \\
(0.16 \mathrm{~mm})\end{array}$ & $\begin{array}{c}0.25 \mathrm{pt} \\
(0.08 \mathrm{~mm})\end{array}$ & $\begin{array}{c}0.25 \mathrm{pt} \\
(0.08 \mathrm{~mm})\end{array}$ & $\begin{array}{c}0.25 \mathrm{pt} \\
(0.08 \mathrm{~mm})\end{array}$ \\
\hline
\end{tabular}

Risk of rejection by incompatibility of paints is eliminated by using a trap.

It is well known that in color printing, color is set using color separation, that is, the synthesis of several colors.

Therefore, the analysis of the lightness of objects should be done separately for each ink used for printing.

Most often, a CMYK system containing four base paints is used. However, it is not uncommon to use other colors (the so-called Spot color, for example, the Pantone system).
All the colors used in the synthesis of color will be called components of this color, and colors containing more than one component are composite.

The dark paint (component) in CMYK is black. It is achromatic, so the black ND (Black)=D (Black). With other paints it is more difficult.

In trapping systems, special tables are used to store ND color values, which usually contain not only typical values for popular triads (Table 5), but also detailed tables of colors (color tables) for Pantone libraries. It is also possible to calculate ND with CMYK or Labcolor coordinates, but the accuracy of this method is somewhat lower. In practice, a certain decrease in accuracy associated with the application of the averaged data from these tables (or ND calculation with CMYK) is entirely acceptable.

In special cases, it is necessary to use densitometers, with which it is possible to accurately measure ND ( $\mathrm{V}$-visual mode).

Table 5

The Neutral Density parameter value in the two popular triads

\begin{tabular}{|c|c|c|c|c|}
\hline ND & Cyan & Magenta & Yellow & Black \\
\hline Euro & 0.51 & 0.62 & 0.04 & 1.67 \\
\hline SWOP & 0.60 & 0.76 & 0.16 & 1.73 \\
\hline
\end{tabular}

The Neutral Density parameter is the decimal logarithm from the neutral component level. This logarithm is convenient because the ND of the compiled color is simply the arithmetic sum of the ND components.

Obviously, there will be no problems between objects with colors C100 and C50. In such a pair of forums, cutting down, so there is no risk of artifacts. Similarly, in complex colors. For example, the color of the C50M50Y50 is derived from the C70M80Y100 (Table 6) - in such pair, trapping is meaningless. The second color consists entirely of the components of the first, so there is also no felling in such a pair. It is customary to say that in this case the first color is derived from the second. Note that the colors can vary significantly, but from the point of view of the trap they will be «related».

Table 6

Color analysis by component

\begin{tabular}{|c|c|c|c|c|}
\hline $\begin{array}{c}\text { Color } \\
\text { components }\end{array}$ & Color 1 & Color 2 & Difference & Trapping \\
\hline C & $70 \%$ & $50 \%$ & $20 \%$ & $>$ \\
\hline M & $80 \%$ & $30 \%$ & $50 \%$ & $>$ \\
\hline$Y$ & $100 \%$ & $60 \%$ & $40 \%$ & $>$ \\
\hline K & $0 \%$ & $0 \%$ & $0 \%$ & No need \\
\hline \multicolumn{6}{|c|}{ Conclusion: all components in one direction } & No need \\
\hline
\end{tabular}

The color difference in the pair does not exceed the color step limit. The threshold at which the difference will be considered insignificant is usually called the color step limit. For typical commercial products, the typical value of step limit is $25 \%$.

From Table 7 it is seen that the component differences are opposite directions. In modern trapping systems, 
a relative method of calculating the color difference is applied, i.e. relative color step limit. It is defined as the difference, divided by the smaller of the color values. But in the event that the absolute difference is less than $5 \%$, the relative value is not calculated, and this component is not considered.

Table 7

Absolute and relative color difference

\begin{tabular}{|c|c|c|c|c|c|}
\hline $\begin{array}{c}\text { Color } \\
\text { components }\end{array}$ & Color 1 & Color 2 & Difference & $\begin{array}{c}\text { Relation to } \\
\text { difference }\end{array}$ & Trapping \\
\hline C & $15 \%$ & $5 \%$ & $10 \%$ & $10 / 5=200 \%$ & $<$ \\
\hline M & $25 \%$ & $35 \%$ & $10 \%$ & $10 / 25=40 \%$ & $>$ \\
\hline Y & $50 \%$ & $60 \%$ & $10 \%$ & $10 / 50=20 \%$ & No need \\
\hline K & $15 \%$ & $10 \%$ & $5 \%$ & Not calculated & No need \\
\hline $\begin{array}{l}\text { Conclusion: there are two components, a reference which dif- } \\
\text { ference is greater than the relative step limit, and they are in } \\
\text { the opposite direction }\end{array}$ & Need \\
\hline
\end{tabular}

Thus, we will consider two components to be equal to each other if the value of one exceeds the value of the other by the value of the relative step limit. Then Trapping between two colors is not needed if all the components of the same color are greater or equal (taking into account the relative step limit) of the corresponding components of the second color.

The results of the research on the development of methodological bases for supporting the work of the prepress engineer were implemented in the form of an information support system. In Fig. 4 shows the sketch of the main page of this system.

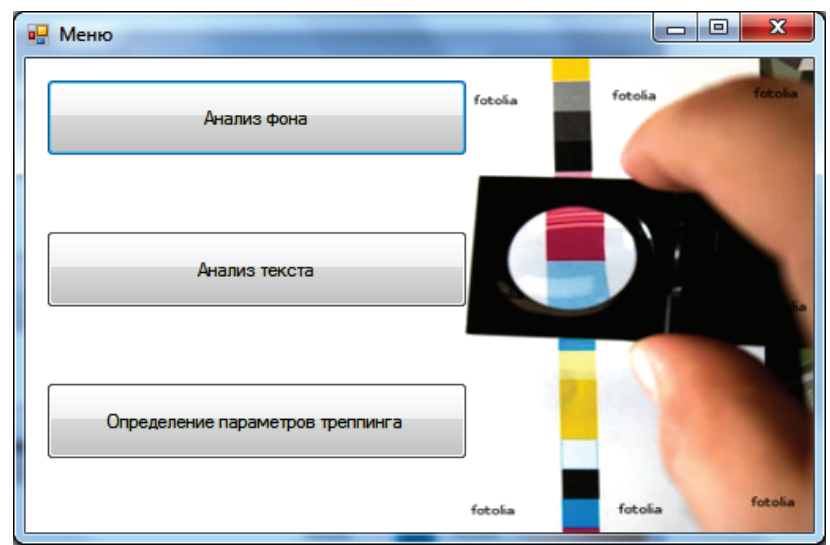

Fig. 4. Sketch of the main menu of the information support system of the prepress engineer

Fig. 5 shows a sketch screen of background analysis

The work of this window consists in analyzing the background and revealing the correspondence of the characteristic features of color reproduction, in choosing the optimal total percentage of colors that will be printed on the printout with a minimum deviation from the required result.

Fig. 6 shows a sketch of the trap definition screen.

The result of this window is the use of a prepress engineer under certain conditions of parameters trap and overprint. These parameters are determined by analyzing the color of two objects lying on top of each other.

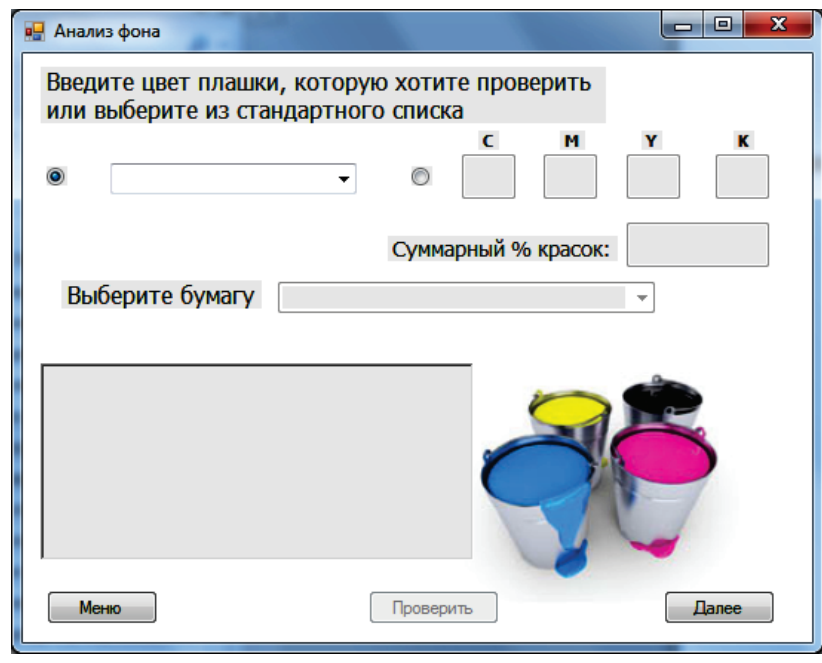

Fig. 5. Sketch of background analysis

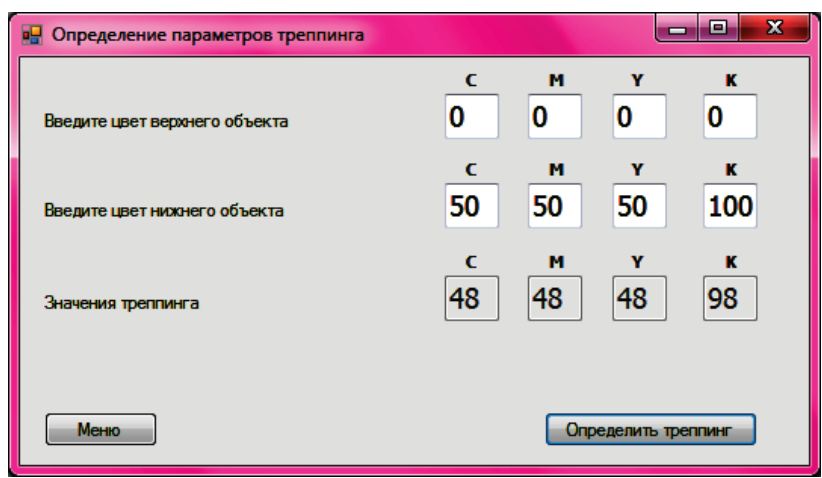

Fig. 6. Sketch screen definition trapping parameters

\section{SWOT-analysis of research results}

Strengths. The advantages of the proposed method of supporting the work of the prepress engineer are:

- ensuring consistency of the components of the layout verification process for correct color rendering;

- presence of the formalized algorithm in the form of structured stages of work of the prepress engineer; - ensure the issuance of valid recommendations to the pre-engineer with the help of a projected information support system.

Weaknesses. The weaknesses of the conducted study include the fact that the information-support system is designed only for the CMYK color model. As a result of using the developed information system, it can be difficult for a different spectrum of color models.

Opportunities. Further areas of research may include: - evaluation of the effectiveness of using the information support system of the prepress engineer in the prepress process;

- optimization of the lineature of printing taking into account the probable area of the trap;

- development of a methodology for assessing the quality of the trap based on the use of the information support system of the prepress engineer.

Threats. The main difficulties of the subjective nature of the implementation of research results in the enterprise are: - the need to work with expert experts to determine the most significant factors of a publishing and printing 
company to optimize the prepress preparation of the publication;

- determination of the significance and strength of each factor on the color management process.

The involvement of experts is necessary to assess the degree to which the image meets the requirements of color reproduction and to determine the systematic nature of measuring color parameters.

Determination of these parameters should be carried out within the following stages of the technological process of printing products, such as design, prototyping, preparation of printed forms, making a test print, printing of the circulation.

In the process of realization of the following directions of research the following difficulties may arise:

1) so, during the evaluation of the effectiveness of the use of information support system of the prepress engineer in the process of prepress preparation it may be difficult to determine the integral indicator of such efficiency and quantify each component of this indicator;

2) optimization of printing linearity, taking into account the likely area of trapping, may face the problem of a significant variation of this value, depending on printing technology, technical characteristics of the mold equipment and printing machine;

3 ) in the process of developing a methodology for assessing the quality of traps based on the use of the information support system of the prepress engineer, it may be difficult to distinguish the utility factors of this system for publishing practice.

\section{Conclusion}

1. The characteristic features of color is determined in terms of the work of the prepress engineer. It is found out that the main points which always need to be taken into account when conducting preprinting are the regime of consistent rendering of paint and the printing mode overlay.

2. The technology of mixed color management is proposed. The result of the implementation of this technology is the following recommendations:

- for the creation of gradient fills and other similar effects with the transition «in white» as the final value of white, the initial mixed color with the value Tint $=0 \%$;

- to create gradient fills and other similar effects with the transition in «transparent» it is more reliable to apply the transition mode «in white» with the installation of the printing attribute with the overlay;

- to create complex interactions between triads and blends should be used combinations of objects using the overprinting attribute.

3. An algorithm for recording the characteristics of color rendering is created. As a result, the main contra- dictions concerning the use of color are resolved, and the methodical recommendations for the support of the prepress engineer are received taking into account the correct color reproduction.

4. Automation of the process of determining the parameters of trapping is carried out. This automation gives the prepress engineer the following capabilities:

- creation of a database, operational information files for color rendering;

- obtaining recommendations for the analysis of individual objects at different stages of work;

- further use of the information support system as a guide.

\section{References}

1. Synnott J., Dietzel D., Ioannou M. A review of the polygraph: history, methodology and current status // Crime Psychology Review. 2015. Vol. 1, No. 1. P. 59-83. doi:10.1080/ 23744006.2015.1060080

2. Urbas R., Stankovic U. Color differences and perceptive properties of prints made with microcapsules // Journal of Graphic Engineering and Design. 2015. Vol. 6, No. 1. P. 15-21.

3. Screen-offset printing for fine conductive patterns / Nomura K. et al. // Microelectronic Engineering. 2014. Vol. 123. P. 58-61. doi:10.1016/j.mee.2014.05.009

4. Chitradevi B., Srimathi P. An Overview on Image Processing Techniques // International Journal of Innovative Research in Computer and Communication Engineering. 2014. Vol. 2, No. 11. P. $6466-6472$.

5. Aralova N. I., Kyiashko O. Y. The Method of Technology Evaluation Based on Improved Cost Approach // Science and Innovation. 2017. Vol. 13, No. 3. P. 65-76. doi:10.15407/ scine13.03.065

6. Kapela R., McGuinness K., O'Connor N. E. Real-time field sports scene classification using colour and frequency space decompositions // Journal of Real-Time Image Processing. 2014. Vol. 13, No. 4. P. 725-737. doi:10.1007/s11554-014-0437-7

7. Mulisch M. Tissue-Printing. Heidelberg, 2014. 24 p. doi:10.1007/ 978-3-658-03867-0

8. Samarin Yu. Kontrol' kachestva dopechatnoi podgotovki izdanii // KompiuArt. 2012. No. 2. URL: http://www.compuart. ru/article.aspx?id=22838\&iid=10 (Last accessed: 15.03 .2018 ).

9. Adaptive Image Processing Algorithms for Printing / Safonov I. et al. Heidelberg: Springer Spektrum, 2018. 304 p. doi:10.1007/978-981-10-6931-4

10. Aleksieienko N. Quality assessment of preprint preparation for book edition // ScienceRise. 2017. Vol. 9, No. 38. P. 29-32. doi:10.15587/2313-8416.2017.110976

11. Gubnytska J. S., Gurieva N. S. Methods of Workflow Controlling in Treatment of Text and Graphic Information // Information Processing Systems. 2012. Vol. 1, No. 3 (101). P. 127-133.

Hrabovskyi Yevgen, PhD, Associate Professor, Department of Computer Systems and Technologies, Simon Kuznets Kharkiv National University of Economics, Ukraine, e-mail: Yevgen.Hrabovskyi@hneu.net, ORCID: https://orcid.org/0000-0001-7799-7249

Yevsyeyev Oleksiy, PhD, Associate Professor, Department of Computer Systems and Technologies, Simon Kuznets Kharkiv National University of Economics, Ukraine, e-mail: yevsyeyev@gmail.com, ORCID: https://orcid.org/0000-0002-6464-7036 